\title{
CONTINUITY, DISCONTINUITY, AND HOPE \\ The CONTRIBUtion OF NEW TESTAMENT ESCHATOLOGY TO A \\ DISTINCTIVELY CHRISTIAN ENVIRONMENTAL ETHOS
}

Jonathan Moo

\begin{abstract}
Summary
This article focuses on the interpretation of three texts-Romans 8 , 2 Peter 3, and Revelation 21-22-to develop the exegetical basis for a distinctively Christian perspective of the future that has important implications for how we understand our task in and for the created world. I propose that the diverse ways in which the NT portrays the future of the earth, taken together, provide an indispensable resource for the development of a Christian environmental ethos. I argue that this resource is not rendered more valuable by well-intentioned attempts to collapse the different emphases that emerge from, say 2 Peter 3 and Romans 8, into one version or the other. Nonetheless, I also argue that the contradiction that is often felt to exist between these different portraits of creation's future is not so acute that we cannot identify vital strands of continuity between them; and, most importantly, that the ecological ethos that emerges from serious reflection on the implications of these visions is as radical as it is consistent with the OT prophets in their stern calls for righteousness and justice to be realised on earth.
\end{abstract}

\section{Introduction}

Twenty years ago, the 1989 Tyndale Lecture in Ethics was delivered by the Oxford economist Donald Hay. ${ }^{1}$ The title of his lecture,

1 The present article is a lightly revised version of the 2009 Tyndale Lecture in Ethics and Social Theology, delivered in Cambridge on 9 July 2009. I am particularly grateful for the opportunity to have given this lecture in a year when the Ethics and 
'Christians in the Global Greenhouse?', suggests that Hay was prescient in identifying early on the significance of what has come to be considered one of the greatest challenges facing life on earth. ${ }^{2}$ Only the question mark at the end of his title would be less appropriate if he were delivering the lecture today. Every one of the past twenty years has been significantly above the long-term average in global temperature. Thirteen of them have in fact been hotter than any year recorded prior to 1989, and the ten hottest have all occurred within the last twelve. Even 2008, a year widely hailed by sceptics and a sensationalist media alike as evidence that the climate is now cooling, was still the ninth or tenth warmest on record, and this despite a strong La Niña and a record low solar minimum. ${ }^{3}$

Debate in the scientific community has progressed from questions about whether the climate is warming and whether greenhouse gas emissions are a significant contributor to this warming to questions about the precise magnitude of future temperature increases to be expected, what the wider effects might be and what can be done about it. The science has continued to move forward; but little of substance has yet changed on the political front. ${ }^{4}$ Despite plenty of rhetoric, on the ground (or, rather, in the air) greenhouse gas emissions have continued to increase globally year on year. It is little wonder that some keen observers have begun to despair, suggesting that it is already too late to do anything to prevent catastrophic climate change. ${ }^{5}$ University

New Testament groups were meeting together. I am thankful to those present for their questions and comments.

2 The Inter-governmental Panel on Climate Change (IPCC) released its first report in the following year. Hay's lecture was published as 'Christians in the Global Greenhouse?', TynBul 41 (1990): 109-127.

3 For up-to-date data and analysis of the global temperature record, see especially the websites run by the University of East Anglia's Climatic Research Unit at http:// www.cru. uea.ac.uk [accessed 27 July 2009] or NASA's Goddard Institute for Space Studies at http://data.giss.nasa.gov [accessed 27 July 2009].

4 This essay is being written in the months leading up to the 2009 Copenhagen Summit; it is not yet clear what results might follow from this potentially critical meeting.

5 James Lovelock is perhaps the most well known and outspoken in this respect, but there are many more mainstream and respectable voices within the scientific community who share something of his pessimism. Even the generally cautious IPCC's most recent report concludes that it is now 'very unlikely' that a global temperature rise of 2 degrees Celsius will be avoided. Shortly after the report's release, Professor Martin Perry of the UK's Met Office claimed that, 'Even if we achieve a cap at two degrees, there is a stock of major impacts out there already and that means adaptation. You cannot mitigate your way out of this problem. ... The choice is between a damaged world or a future with a severely damaged world' (quoted in Cahal 
lecture series in climate change mitigation are giving way to lectures on climate change adaptation. Western governments are being forced to consider seriously just how they will deal with challenges ranging from rising sea levels to the hundreds of millions of environmental refugees that global warming is likely to create in the coming decades.

And if there are signs of gloom among global-warming activists, there are even greater reasons for despair among those who labour to address more traditional environmental problems. Global warming may indeed be the most pressing and potentially catastrophic challenge facing us, but the unprecedented explosion in human population that has occurred over the last century, combined with our ever-growing rates of consumption, have many more mundane and much more predictable effects on land, water, and fellow creatures. There is not space to detail any of this here, but - for an easily accessible place to start-readers might consult the sober (and sobering) assessment provided in the United Nations Global Environment Outlook. ${ }^{6}$ This report, incidentally, treats the effects of environmental degradation only from the standpoint of human life and well-being. Debates about whether the earth and its creatures have independent value and merit consideration in their own right tend to fall by the wayside when the threats to humankind itself are so great. ${ }^{7}$

What does any of this have to do with Christian faith? Some early suggestions that Christianity and the worldview it engenders is actually responsible for the global environmental crisis have been largely refuted on historical grounds or at least have given way to more nuanced accounts. But the church today, especially in its evangelical expressions, still seems uneasy and uncertain about just what role it ought to play. There are those who argue strongly that Christians ought to jump on the bandwagon of environmentalists or global-warming

Milmo, “"Too Late to Avoid Global Warming," Say Scientists', The Independent (19 September 2007) http://www.independent.co.uk/environment/climate-change/too-lateto-avoid-global-warming-say-scientists-402800.html [accessed 27 July 2009]: para. $10)$.

6 The most recent version of this report, the fourth, was released in 2007 and is available as a free download at http://www.unep.org/geo [accessed 27 July 2009].

7 J. Baird Callicott has nonetheless made a convincing case for why the question of nature's intrinsic value still demands to be answered even when purely anthropocentric approaches to environmental ethics converge with those based on some notion of nature's intrinsic value (Callicott, Beyond the Land Ethic: More Essays in Environmental Philosophy [Albany, NY: State University of New York, 1999]: 24146). 
activists; and there are others who argue just as strongly that environmentalism represents a threat to economic growth and traditional values and so Christians should oppose attempts to mitigate climate change or to implement costly environmental programmes. Popular among many evangelicals is the apparently more innocuous notion that Christians ought to get on with proclaiming the gospel and let the rest of the world sort out such earthly problems. A large body of literature has unsurprisingly grown up to explore each of these and many other approaches, with most of those who bother to write about it naturally calling for greater Christian involvement in caring for the earth (although the United States has remained a robust market for contrarian perspectives).

Meanwhile, it has to be said that until recently the handful of biblical scholars who have bothered to ask whether Scripture provides any resources for thinking about these questions have often ended up carrying on their conversations within self-contained ghettos of the like-minded. A retreat to exclusively hermeneutical questions and a turn to reader-response criticism has left many fellow researchers (and certainly most ordinary Christians) bemused and in any case largely free to ignore the fruits of their work. The lack of a strong connection between exegesis and Christian environmental ethics has also at times been perpetuated by sharp academic divides between theology, ethics, and biblical studies, even if the genuinely difficult hermeneutical problem of whether and how Scripture can be used to address contemporary issues refuses to go away. In any case, there are still too few bridges between exegesis and environmental ethics; and would-be bridge builders are perhaps put off by the knowledge that on the one side they are likely to be attacked by biblical scholars who find their constructions anachronistic and lacking adequate exegetical foundations and that on the other side they are likely to be met by environmental ethicists who are not interested in the sort of incoming traffic that such bridges encourage.

I obviously cannot hope to address all of these issues in this paper, so I will proceed from the assumption that the mission of the Christian church does necessarily include concern with such earthly problems as environmental degradation, unsustainable resource use, ecosystem integrity, and the plight of the poor and of future generations. Moreover, although I take it for granted that the Christian Scriptures, and the NT in particular, have little or nothing to say directly about so- 
called environmental issues, I am convinced that if Scripture has much to tell us about who we are, who God is, and how we ought to live in the world, it has tremendous potential to shape us into the sort of people from whom particular responses to even a new challenge like the global environmental crisis will be expected and indeed required.

But rather than merely arguing that we ought to take science seriously and to care more wisely for the earth, I want to consider what can be distinctive about a Christian environmental ethos. There is no reason why Christians should not make common cause with those of other faiths or none to work for a more just and sustainable world, but I want to suggest that as Christians our motivation, our purpose, and our hope will necessarily be different from those of our co-belligerents who do not profess biblical faith; and there will be times when these differences will also lead to differences in method and approach. I intend to argue that it is especially the eschatological perspective of the NT that can provide a distinctive lens for understanding the created world and the Christian's role within it.

My emphasis on NT eschatology is not meant to imply that it is only here that the biblical tradition has something to contribute to a Christian environmental ethos. Stephen Williams has reminded us that love must always remain at the centre of Christian social and environmental action - and indeed, at the centre of any discussion about eschatology. ${ }^{8}$ Whatever the future holds, we are called to love and care for the world as we encounter it. Nonetheless, the NT's theology of creation is inescapably eschatological, and the wideness of biblical hope can provide both a strong impetus as well as the necessary context for the exercise of Christian love and charity.

This essay seeks, then, to develop somewhat further than is often done the exegetical basis for a distinctively Christian perspective of the future that has important implications for how we understand our task in and for the created world. I propose that the diverse ways in which the NT portrays the future of the earth, taken together, provide an indispensable resource for the development of a Christian environmental ethos. I argue that this resource is not rendered more valuable by well-intentioned attempts to collapse the different emphases that emerge from, say 2 Peter 3 and Romans 8, into one

8 Stephen Williams, 'Thirty Years of Hope: A Generation of Writing on Eschatology' in 'The Reader Must Understand': Eschatology in Bible and Theology, ed. K. E. Brower and M. W. Elliott (Leicester, UK: Apollos, 1997): 243-58. 
version or the other. Nonetheless, I also argue that the contradiction that is often felt to exist between these different portraits of creation's future is not so acute that we cannot identify vital strands of continuity between them; and, most importantly, that the ecological ethos that emerges from serious reflection on the implications of these visions is as radical as it is consistent with the OT prophets in their stern calls for righteousness and justice to be realised on earth. Thus part of my argument rests on the observation that when the biblical (by which I mean the OT) and Jewish contours of the NT's theology of creation and new creation are taken seriously, the significance of the Hebrew Bible's concern for the land can find fresh ways of being expressed within a contemporary ethos of care for the earth. In what follows, I will focus on just a few key texts, moving from Romans 8 to 2 Peter 3 and finally to Revelation 21-22.

\section{Romans 8}

Romans 8:18-25 is a popular text with Christian environmentalists. The passage is used uncritically at times and perhaps too often is cited in isolation from what the rest of the NT has to say about creation and eschatology, ${ }^{9}$ but for all that, it does provide a vital foundation in the construction of a biblically-rooted environmental ethos. Here Paul's story of human redemption in Christ is seen in its full cosmic context; here we have confirmation, if it were needed, that Paul's gospel has not left behind the groaning earth whose restoration the OT prophets assumed would accompany the liberation and transformation of God's people.

Nearly all commentators on Romans 8 now accept that ktisis refers in this passage to 'creation' and especially to the non-human creation. ${ }^{10}$ In verse 21 , the 'creation itself' is linked with but distinguished from the 'children of God', with whom it looks forward to sharing in the glorious freedom to come. In the present age, however, creation is said

9 See the assessment of different interpretative approaches in Cherryl Hunt, David G. Horrell, and Christopher Southgate, 'An Environmental Mantra? Ecological Interest in Romans 8:19-23 and a Modest Proposal for Its Narrative Interpretation', JTS 59 (2008): 546-79.

10 See especially the concise case for this made by C. E. B. Cranfield, A Critical and Exegetical Commentary on the Epistle to the Romans, vol. 1 (ICC; Edinburgh: T \& T Clark, 1975): 411-12; more recently the consensus has been upheld by Robert Jewett, Romans (Hermeneia; Minneapolis: Fortress, 2007): 511-12. 
to be subjected to futility. James Dunn helpfully unpacks Paul's rather compressed thought at this point: 'God subjected all things to Adam, and that included subjecting creation to fallen Adam, to share in his fallenness'. ${ }^{11}$ That creation is subjected to futility in being subjected to humankind is something of an ironic reversal of the usual biblical pattern in which human beings become subject to futility by worshipping created things instead of the creator. The background for Paul's thought here likely includes the prophetic motif of the earth's suffering and mourning under human evil and injustice, especially as this is developed in Isaiah 24. If this is the case, then creation's subjection and groaning denotes for Paul not only the immediate result of Adam's rebellion and the curse pronounced in Genesis 3 but also the ongoing effects of this state of affairs as they continue to be played out in the relationship between God, his rebellious human creatures, and the earth itself. ${ }^{12}$ The groaning of creation is something that continues, Paul says, even into the present time.

It is difficult for today's ecologically-aware reader not to equate this picture of creation's groaning with modern scenes of environmental ruin. Paul did not of course envision the sorts of threats to life on earth that we now face, but that does not mean that such a link is as anachronistic as it first appears. For it is precisely in the link that Paul perceives between humankind and the rest of creation that today's global environmental crises are explicable within a Christian worldview. When this biblical perspective is taken seriously, it should hardly be a surprise to find that human greed and injustice-and sometimes just plain ignorance-is capable of leading to such frightening consequences for the earth as we have begun to witness in our time. But Paul's purpose in Romans 8 is not simply to make the negative point that creation has found itself subjected to futility in being subjected to humankind. Paul's intent is rather to assure readers that this is not the end of the story, for them or for the earth. Creation itself groans with them in their suffering as they eagerly anticipate the realisation of the hope to be revealed as who they truly are, children of God and co-heirs with Christ. In verse 23, Paul makes it clear that this coming revelation of the children of God will be brought about in the 'redemption' of their 'bodies', in the resurrection. Creation's future is

11 James Dunn, Romans (vol. 1 WBC; Dallas: Word, 1988): 471.

12 Jonathan Moo, 'Romans 8.19-22 and Isaiah's Cosmic Covenant', NTS 54 (2008): 74-89. 
thus bound up with the future of God's children, and this future consists in resurrection and the liberation of creation itself.

Romans 8 in fact lends support for the idea that the resurrection of the body is an appropriate NT model for envisioning the material restoration of all of creation. This would suggest that what Paul says elsewhere about glorifying God with the physical body, for example in 1 Corinthians 6:12-20, may be of some relevance for considering how God may be glorified by living rightly within creation - in ways that respect its integrity, value, and God's ultimate purposes for it. As Paul says of the body, the earth does not finally belong to us; and its future too has been bought at a price, since in Paul's conception creation cannot attain its telos unless and until those human creatures to whom its fate is linked become who they are intended to be in Christ. Colossians 1:20, where God through Christ 'was pleased to reconcile to himself all things, whether on earth or in heaven, by making peace through the blood of the cross', is perhaps more explicit in presenting Christ's atoning work as having cosmic significance in and of itself; but in Romans 8 the ramifications of God's redemption in Christ are no less significant for the entire creation, even if they are here portrayed as in some sense mediated through those human creatures whose adoption as God's children Christ has secured.

The full revelation of God's children must await the resurrection, but for Paul the new creation has already in some sense broken into the old. As he says in 2 Corinthians, 'If anyone is in Christ, there is new creation!' (5:18). The children of God are-even within Romans 8thus declared by Paul in verse 16 already to be God's children now, the Spirit testifying to their identity as children of God and co-heirs with Christ. As often for Paul, the ethical imperative that necessarily follows is that God's children begin to live now as who they truly are and as they one day will be fully revealed to be. And if God's children do begin to live as who they are, it is surely appropriate to expect that the non-human creation ought also to begin to experience something of its future liberation from its subjection to futility and ruin. Reconciliation with God through Christ must mean humankind's reconciliation with the earth too. There is support here for Jürgen Moltmann's claim that 'there is no fellowship with Christ without fellowship with the earth. 
Love for Christ and hope for him embrace love and hope for the earth'. ${ }^{13}$

There is much more that could be said, but, by way of summary, I would suggest that the importance of Romans 8 for formulating a Christian environmental ethic lies in the first instance in the continuity that Paul assumes exists between the present creation and the new creation to come. Whatever elements of discontinuity there may also be, it can be nothing other than the same creation that is now groaning that will one day be released from its present subjection to futility and come to share in the glorious freedom of the children of God. According to Paul, the resurrection of the body is accompanied byand perhaps is rightly seen as a model for-the renewal of creation itself. The ethical implications of this for living in right relationship with the rest of creation are not of course developed by Paul, but I would suggest that they emerge quite powerfully all the same.

Romans 8 also indicates that for Paul-as for other biblical writers - the whole of creation's fate is mysteriously bound up with the fate of one of its creatures - humankind. In our own day, such an idea might seem naïve, aware as we are of the billions of years that the earth existed before human beings and the billions of years that it would seem to be able to go on without us. But ironically we are also far more aware today than at any other time of humankind's potential radically to alter the earth and to affect its life; so, in one sense, it should be clearer than ever that the future of the world - at least as we know ithas become bound up with our future, for good or for ill. But more fundamentally, of course, what Scripture suggests about creation's future is something beyond any mere extrapolation of present conditions. The ultimate future lies in the hands of the one who calls into being that which is not; according to the NT, individual and cosmic futility are finally reversed only in resurrection and new creation. The call for those who are in Christ is to live as beachheads of that new creation in the present age, to engage in what Dietrich Bonhoeffer calls 'truly responsible' action that reflects care for the penultimate in the light of God's ultimate future. ${ }^{14}$

13 Moltmann, The Coming of God: Christian Eschatology (tr. M. Kohl; Minneapolis: Fortress, 2004): 279.

14 I am indebted at this point to the way in which Bonhoeffer's language relating to ethics and eschatology has been developed and applied by Neil Messer, Selfish Genes 


\section{2 Peter 3}

If Romans 8 is the most popular text with Christian environmentalists, 2 Peter 3 is perhaps the least. At the November 2008 meeting of the Society of Biblical Literature's Ecological Hermeneutics group, Barbara Rossing went so far as to claim that there is nothing redeemable in this passage. ${ }^{15}$ According to Rossing (and many other contemporary interpreters), 2 Peter 3 cannot be reconciled with what other portions of the NT teach about the earth, and it has nothing helpful to say to Christians today. My argument in this paper is quite different. I will first argue at some length that the eschatological picture painted so vividly in 2 Peter 3 is not in any necessary conflict with that of Romans 8, for example, and that the emphasis in 2 Peter on discontinuity between the present world and the world to come does not in fact entail the sort of world-denying 'pie in the sky' mentality that it is so often assumed to encourage. But I also want to suggest that this passage's undoubted emphasis on judgement and discontinuity is a theme that must in any case be taken seriously. To ignore it is to risk missing what is a potentially distinctive and important component of a Christian environmental ethos. ${ }^{16}$

It is generally assumed that 2 Peter 3 unequivocally portrays the complete dissolution of the present cosmos and its replacement with a new heaven and a new earth. Edward Adams, to take a recent example, concludes at the end of what is a thoughtful and thorough study that '[t]he writer has expressed the conviction that the existing created order will come to a violent end as emphatically as he could' ${ }^{17}$ I will call attention to some features of the passage that might support a more cautious assessment, but there can be no doubt that the emphasis here is on the radical discontinuity envisioned between the present age and the age to come. The author of 2 Peter is in fact addressing those who

and Christian Ethics: Theological and Ethical Reflections on Evolutionary Biology (London: SCM, 2007): 207-11, esp. 211.

15 Barbara Rossing, 'Apocalyptic Discourses, Global Warming, and Empire: Is This the End of the World?' (Paper presented at the 2008 Annual Meeting of the SBL, Boston, 24 November 2008).

16 In this section on 2 Peter 3 I have partly reproduced and expanded material that appears in Jonathan Moo, 'Environmental Unsustainability and a Biblical Vision of the Earth's Future' in Creation in Crisis: Christian Perspectives on Sustainability, ed. R. S. White (London: SPCK, 2009): 255-70, here 261-69.

17 Edward Adams, The Stars Will Fall from Heaven: Cosmic Catastrophe in the New Testament and Its World (LNTS 347; London: T\&T Clark, 2007): 234. 
claim that things will carry on as they always have; and he uses powerful imagery to refute them, making the point that not only has God judged the world in the past but that he will do so again in the future.

The events associated with the 'day of the Lord' are described with three short clauses in verse 10: 'the heavens will pass away with a loud noise, and the elements will be dissolved with fire, and the earth and everything that is done on it will be disclosed'. As is well known, older translations of the final phrase have the earth and the works on it being 'burned up' rather than 'found' or 'disclosed' as in the NRSV cited here and in most other modern translations. The difference is due to a number of textual variants in the verse, but nearly all present-day commentators accept what is the best supported, though more difficult reading, عúpєӨท́бєtå (heurethēsetai; 'will be found'), not only because of the powerful manuscript evidence ${ }^{18}$ but precisely because all of the other variants can be explained as attempts to clarify this rather unusual way of describing the final judgement. ${ }^{19}$ The possible

18 The range of readings and their manuscript support is presented most clearly in

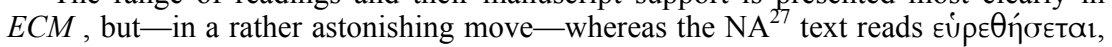

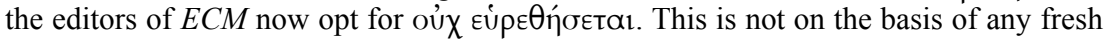
manuscript evidence (indeed, there is no Greek evidence for this reading whatsoever; it finds support only in the Syriac Philoxeniana and in the Sahidic), but evidently the change has been made because the editors have decided to treat all of the readings that attest to the idea of destruction, burning or removal as mutually supportive rather than as reflecting - as Richard Bauckham and others have convincingly argued (see below, n. 19) - different scribal attempts to correct what may have been a difficult (but not impossible) original reading, єúpєӨ́ंбєtal (which is attested by Sinaiticus (01), Vaticanus (03), 018, 025, 323, 424Z, 1175, 1241, 1448, 1739T, 1852, 1881, and some Syriac MSS). Bauckham's explanation is a more economical one than either of the alternative explanations which would seem to be required by the reading of $E C M$, i.e.

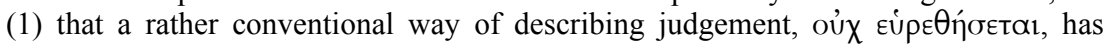
occasioned such a wide diversity of glosses and alternative readings, or (2) that the negative particle was lost at a very early stage and yet somehow preserved (only?) in the manuscript(s) available to the Syriac and Sahidic translators.

19 See Richard Bauckham, Jude, 2 Peter (WBC 50; Waco, Tex.: Word Books, 1983): 303, 316-21; Al Wolters, 'Worldview and Textual Criticism in 2 Peter 3:10', WTJ 49 (1987): 405-413, esp. 405-408; Eric Fuchs and Pierre Reymond, La deuxième épitre de Saint Pierre / L'épitre de Saint Jude (CNT 2.13b; 2nd edn; Geneva: Labor et Fides, 1988): 117; Henning Paulsen, Der Zweite Petrusbrief und der Judasbrief (KEK 12/2; Göttingen: Vandenhoeck \& Ruprecht, 1992): 168; Jerome H. Neyrey, 2 Peter, Jude (AB 37c; New York: Doubleday, 1993): 243-44; Anton Vögtle, Der Judasbrief / Der 2. Petrusbrief (EKK 22; Neukirchener-Vluyn: Neukirchener, 1994): 234-38; Daniel J. Harrington, Jude and 2 Peter (SP 15; Collegeville, Minn.: Liturgical, 2003): 289 (although Harrington finds it necessary to translate the last clause as a question- 'will they be found?'); Peter H. Davids. The Letters of 2 Peter and Jude (PNTC; Grand 
significance of this terminology will be taken up shortly. First, however, it is necessary to consider the meaning of another difficult term in this verse and the wider background for 2 Peter's language and ideas.

The referent of the 'elements' (stoicheia), which are said to be destroyed by 'fire' or 'burning' in verse 10 and to 'melt with fire' in verse 12 , remains a subject of much debate. Adams is a strong advocate of the view that the author of 2 Peter draws heavily on Stoic cosmology to refute the arguments of his opponents, and, if Adams is right, stoicheia should almost certainly be interpreted as referring to the four constituent elements of the world - water, fire, earth, and air. This, as Adams points out, is how the term was regularly used and understood in Stoicism as well as in the wider Greek-speaking world. ${ }^{20}$ According to Adams, the 'elements' are then essentially equivalent to the 'earth'; the point of verse 10 is that the heavens and the earth will be destroyed by fire and, in the process, the earth and the works on it will be 'found' in the sense of being judged. ${ }^{21}$ This idea is hinted at already in verse 7 , where the 'present heavens and earth' are said to be 'reserved for fire for the day of judgement and destruction of the ungodly'.

Adams' argument has much to recommend it, and it seems indisputable that many of the first readers of 2 Peter would hear echoes of competing versions of contemporary cosmological 'science', perhaps especially as advanced by Stoics and Epicureans. ${ }^{22}$ Despite the similarities, however, even Adams is forced to concede that there are important differences between Stoic conceptions of the world's end and that which is given in 2 Peter 3 . One obvious difference is that 2 Peter does not envision an infinite cycle of destruction and regeneration, but rather one final and climactic 'day of the Lord'. Moreover, whereas the cause of the world's fiery end in Stoic thought is envisioned as an essentially physical process, the cosmic catastrophe

Rapids and Cambridge: Eerdmans, 2006): 286-87; Gene L. Green, Jude and 2 Peter (BENTC; Grand Rapids: Baker Academic, 2008): 331.

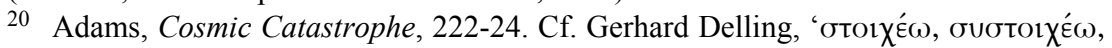
otolxẽ̃ov', TDNT 7: 666-87; Neyrey, 2 Peter, 243.

21 This argument has also been advanced recently by Green, Jude and 2 Peter, 330.

22 Adams, Cosmic Catastrophe, 206-209, rejects the common association of the worldview of the 'scoffers' with Epicureanism, instead linking their thought to the more general Aristotelian belief in cosmic indestructibility. It should be observed, however, that Adams's arguments against a connection with Epicureanism could equally apply to the close connection he claims to find between 2 Peter and Stoicism, where the differences are possibly even more acute. 
of 2 Peter 3 results solely from the creator's prerogative in judgement. It is also telling that the author of 2 Peter does not use the precise terminology we might expect if he intended to call attention to Stoic

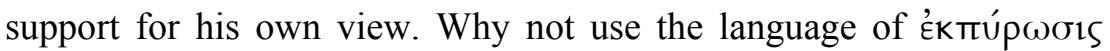

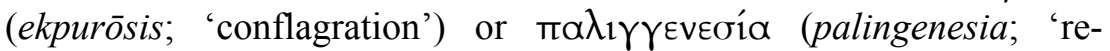
newal', 'regeneration'), for example? While the author of 2 Peter may well have been happy to enlist some Stoic ideas to support his case, the evidence is less compelling than Adams suggests for Stoicism being the primary influence on the way the world's final judgement is here portrayed. The basic impetus and overall shape of 2 Peter's argument seems in the end to remain much nearer to biblical and Jewish apocalyptic thought. ${ }^{23}$

There is in fact an alternative interpretation of stoicheia that takes more seriously the potential OT and Jewish background of 2 Peter and that may better account both for the unusual use of 'will be found' in verse 10 and for the progression in this verse from 'heavens' to 'elements' to 'earth'. By the second century, stoicheia is indisputably used in some instances with the meaning 'heavenly bodies', referring to the stars, sun and moon; ${ }^{24}$ and it is also possible that these material elements of the heavens could be associated with spiritual forces, as may be the case in Paul's use of stoicheia (Gal. 4:3, 9; cf. Col. 2:8, 20). The text of 2 Peter would be the first extant example of an author using stoicheia for 'heavenly bodies', but this meaning for 3:10, 12, has nevertheless managed to garner some substantial scholarly support. ${ }^{25}$ This is primarily because it fits the context so well. On this scenario, the picture presented in verse 10 is something like this: the outer heavens are torn away, the intermediary heavenly bodies are dissolved with fire, and then the earth and all the deeds of human beings are laid bare before God, being 'found' before him, with nothing to separate them from the testing fire of his judgement.

23 This has recently been argued by John Dennis, 'Cosmology in the Petrine Literature and Jude' in Cosmology and New Testament Theology, ed. J. T. Pennington and S. M. McDonough (LNTS 355; London: T\&T Clark, 2008): 157-77, esp. 175-77, who nevertheless is more favourable towards other aspects of Adams's reading.

24 Regularly cited in this regard are Theophilus of Antioch, Autol. 1.4; Justin, 2 Apol. 5.2; Dial. 23.2.

25 E.g. Bauckham, Jude, 2 Peter, 315-16; Paulsen, Der Zweite Petrusbrief, 166-68; Vögtle, Der Judasbrief / Der 2. Petrusbrief, 234; Steven J. Kraftchick, Jude / 2 Peter (ANTC; Nashville: Abingdon, 2002): 163; Davids, 2 Peter and Jude, 284-87. 
Support for such an interpretation can be adduced from the parallel between the way in which the elements are described as 'melting with fire' in 2 Peter 3:12 and the description of God's judgement in Isaiah $34: 4$, where one Greek translation reads, 'all the powers of the heavens will melt'. This version of Isaiah 34:4 is in fact echoed in 2 Clement 16:3, a text which combines Isaiah 34:4 with Malachi 4:1 (3:19 LXX), where the 'day of the Lord' is said to come 'like a burning oven'. According to 2 Clement, the end result of this fiery judgement is that 'the secret and open works of men will appear'. As several commentators have observed, this traditional description of God's judgement does not sound far removed from the rather more unusual way of expressing what may be the same idea in 2 Peter 3:10, where it is said that 'the earth and the works on it will be found'.

Whatever is the precise relationship between 2 Peter and 2 Clement, the latter text reveals the potential for an early Christian writer to envision the final judgement along the lines of the fiery judgement of Malachi 4:1 and to link this with the melting of the heavens (or the powers of the heavens) in Isaiah 34:4 (LXX). ${ }^{26}$ This observation strengthens the possibility that stoicheia in 2 Peter 3 similarly refers to the 'powers of heaven' and not to the melting or destruction of the four components of the earth itself. ${ }^{27}$

Putting all of this together yields a somewhat different interpretation of 2 Peter 3:10 than the popular one to which I alluded earlier. We are left with the cataclysmic fire of God's judgement, but its function in the context is primarily to lay the earth bare before God, to reveal it as it is and to leave human beings and their works without any place to hide. A similar theme could be argued to lie behind Paul's caution that a Christian worker 'build' carefully on the 'foundation' of Christ: 'the work of each builder will become visible, for the Day will disclose it, because it will be revealed with fire, and the fire will test what sort of work each has done' (1 Cor. 3:13). In a somewhat different application

26 Bauckham, Jude, 2 Peter, 304-305, suggests that 2 Peter and 2 Clement are both relying here on a common source.

27 It also calls into question Adams's argument against any possible Jewish or biblical background for the imagery used in 2 Peter 3 . While Adams may be right to point out that 'cosmic conflagration' is not a common motif in the OT or early Judaism, his discounting of the many instances where fire is associated with theophanies or localised judgements (and texts such as Mal. 4:1 or Isa. 66:15-16, where it could be argued there is a more universal scope) as possible sources for such an idea begins to sound like special pleading, especially given his own readiness to see connections with Stoic thought. 
of the same imagery, 1 Peter 1:7 encourages Christians to rejoice in their hope even in the midst of trials so that 'the genuineness of your faith - being more precious than gold that, though perishable, is tested by fire - may be found to result in praise and glory and honour when Jesus Christ is revealed'. Al Wolters is perhaps the strongest advocate for interpreting 2 Peter 3 along these lines, suggesting that the fire here is a purifying fire that destroys human evil but leaves everything else intact or renewed; he goes so far as to suggest that, rather than picturing the end of this creation, 'the text of 2 Pet $3: 10 \ldots$ stresses instead the permanence of the created earth, despite the coming judgement'. 28

Wolters undoubtedly presses his argument too far, but it is striking that nowhere in 2 Peter 3 is the end of the earth unambiguously described. In 2 Peter 3:7, the author does claim that 'the present heavens and earth have been reserved for fire, being kept until the day of judgement and destruction of the godless'; but though both heaven and earth are 'reserved for fire', the purpose of this fire is expressly stated to be for the 'judgement and destruction of the godless'-in other words to do away with human evil. In 2 Peter 3:12, it is again only the heavens and the elements that are said to be burned with fire prior to the appearance of the new creation. More challenging might be $3: 11$, where the author's ethical admonitions are rooted in the fact that 'all these things are dissolving in this way'. The referent of 'all [these] things' would seem in the context to include the heavens, the elements and the earth of the previous verse. ${ }^{29}$ Nonetheless, Peter Davids points out that if 3:10 is taken 'at face value as expressing the vision of the future that our author wishes to communicate, then 'all these things' [in v. 11] are [limited to] the heavens and the elements (heavenly bodies)'; whatever effects such a judgement might also have on the earth, the author's focus remains on 'the positive vision of the future and what it means for the present' ${ }^{30}$

Wolter, Davids, and others have helpfully exposed some potentially deliberate ambiguities in the way 2 Peter 3 portrays the future 'day of the Lord' and its effects on the earth, ambiguities that may call into

\footnotetext{
28 Wolters, 'Worldview and Textual Criticism', 413.

29 Thus Bauckham, Jude, 2 Peter, 324, claims that though the dissolution of the earth is not described in v. 10, the author must, based on v. 11, assume that it too is destroyed.

30 Davids, 2 Peter and Jude, 288.
} 
question Adams's claim that the author has described the violent end of the present creation 'as emphatically as he could'. There is, at the least, some reason to be cautious in our assessment of just what the author intends to describe. Above all, we must finally attend to the implications that the author derives from his eschatological expectations. But before we turn to these implications, it is worth pausing to consider just what the significance might be if the author of 2 Peter 3 does intend to describe the ultimate destruction of the present earth; what, in any case, would 'destruction' mean in such a context?

Adams points out that even when early Jewish and Christian texts do describe a cosmic catastrophe, the absolute destruction of the world into non-existence is never what is in view. The parallel used by the author of 2 Peter himself is instructive; he compares the future judgement by fire with the past destruction of the cosmos by the flood (3:6). This may sound like an intensification of the effects of the Noahic flood described in Genesis, but it is most unlikely that 2 Peter envisions the world that emerged after the flood as anything other than one that was in 'material continuity' with what had existed before. Even the Stoic cycle of cosmic conflagration and regeneration was seen as essentially a purifying and renewing process. Adams himself therefore concludes that 'the destructive process' described in 2 Peter 3 'is part of the process of renewal and renovation (conceived along the lines of the Stoic ekpurōsis), which leads to a new heaven and new earth which stand in material continuity with the present heavens and earth'. ${ }^{31}$ Thus, while I am not persuaded by the degree of importance that Adams assigns to the Stoic background for 2 Peter 3, his conclusions at this point are not far from my own.

It should be evident by this stage that on my reading there is no need to posit any irreconcilable differences between the eschatological conception of Romans 8 and that of 2 Peter 3. Nonetheless, the emphasis in 2 Peter on God's cosmic judgement and on the radical rupture with the past that it entails does represent a challenge to any notion that the new creation emerges slowly in the course of history or through mere human effort. The substantial continuity that Paul assumes in Romans 8 and that I have argued the author of 2 Peter at least allows for in 2 Peter 3 emerges only because of the faithfulness of the God who does not abandon his purposes for his people and his

31 Adams, Cosmic Catastrophe, 259. 
creation even through the discontinuity of death and judgement. And I would argue that for the Christian striving to live as a child of God and to care for a groaning earth, 2 Peter's focus on divine initiative and divine agency can be nothing other than a profound encouragement in an age of environmental despair. As Allen Verhey has said of eschatological hope in general, it frees us from 'the crushing burden of messianic pretensions', from assuming that in the end it is all up to us. ${ }^{32}$

Yet 2 Peter 3 provides a strong warning against complacency. For the author of 2 Peter expects his readers not only to await but, according to verse 12 , even to hasten - to 'speed on' - the coming day of God. The author of 2 Peter explains that the way the day of the Lord is hastened is through 'holy ways of living and godly acts', as the Lord's followers 'strive to be found by him at peace' (v. 14). Steven Kraftchick points out that the plurals in the Greek text, the 'holy ways of living and godly acts', 'underscore that many kinds of godliness characterize the Christian life'. ${ }^{33}$ Presumably this includes cultivating the virtues listed in 2 Peter 1:5-8, where readers are called on to 'support your faith with goodness, and goodness with knowledge, and knowledge with self-control, and self-control with endurance, and endurance with godliness, and godliness with mutual affection, and mutual affection with love'. But it must also include the very many practical things that constitute 'godly acts', concrete examples of goodness, self-control, and love that find expression in different ways in different times and places. And it is precisely here that I would suggest that our scientific knowledge about the present state of the earth, the plight of its people and creatures, and its probable future if things carry on as they have, enters in to supply the context and material with which Christian love and hope must do its work.

It is intriguing that when Jesus talks about the coming of the Son of Man 'like a thief'-the saying echoed in 2 Peter 3:10-Jesus immediately follows this prediction with a parable about a servant whose master has put him in charge of his household. The servant cannot know when his master will arrive, but, in keeping with what has been entrusted to him, the 'faithful and prudent manager' will endeavour 'to be found' working diligently in expectation of the

32 Allen Verhey, Reading the Bible in the Strange World of Medicine (Grand Rapids: Eerdmans, 2003): 140, quoted in Messer, Selfish Genes, 210.

33 Kraftchick, Jude / 2 Peter, 166. 
master's return (Matt. 24:45-51; Luke 12:42-48). Whether or not 'stewardship', at least as it is popularly understood, is quite adequate for capturing the full biblical teaching on humankind's responsibilities within creation, ${ }^{34}$ Jesus' formulation of a stewardship ethic in the context of awaiting the return of the master raises for today's readers the question of what it might mean to be wise stewards in caring for what has been entrusted to us. What does it mean to lead 'lives of holiness and godliness', to care for the earth, and to love our neighbours in a world of staggering inequalities, in countries built upon profligate use and abuse of the planet's resources, and in societies addicted to unsustainable practices that endanger the earth's life, alter its atmosphere, and threaten all who live at the margins? Jesus' stern challenge at the end of his parable in Luke must surely resonate with us in the Western world today: 'From everyone to whom much has been given, much will be required; and from the one to whom much has been entrusted, even more will be demanded' (Luke 12:48).

Before leaving 2 Peter, we must finally consider this passage's compact description of the new creation itself. The language of 'a new heavens and a new earth' is of course borrowed ultimately from Isaiah 65 and 66. But the remarkable personification here of righteousness 'making its home' in the new creation echoes most closely the language of Isaiah 32. In Isaiah 32 there is a vision of God's desolating judgement upon human habitation in the land, which is followed by reference to a time when 'a spirit from on high is poured out on us' and the wilderness becomes a 'fruitful field', a fruitful place where 'righteousness will dwell' (vv. 15-16). 'The effect of righteousness', Isaiah 32 goes on to say, 'will be peace'. In the same way, of course, 2 Peter 3:14 encourages readers, as they await the day of the Lord and the new heaven and new earth, to 'be found by him at peace'. The hope for the future held out by 2 Peter, then, does not sound far from the ecological vision of Isaiah 32, where the wilderness, cleared of human injustice, is renewed by God's spirit as a fruitful field where righteousness dwells and peace is found.

34 See the wide variety of essays assessing the stewardship model in R. J. Berry, ed., Environmental Stewardship: Critical Perspectives-Past and Present (London: T\&T Clark, 2006). 


\section{Revelation 21-22}

The most expansive picture of Christian hope, where the language of Isaiah, Ezekiel, and Jewish apocalypticism finds its fullest NT expression, is found of course in the book of Revelation and in its portrait of the new heaven and new earth. There is also a brief glimpse near the beginning of this book of what the author would consider to be the plight of creation without redemption, of a world without Christ and without hope. This is the moment in the heavenly throne room when the one sitting on the throne is seen holding a sealed scroll in his hand, a scroll that in the context of the narrative must represent the unfolding of God's purposes for the world. No one can be found 'in heaven or on earth or under the earth' who can 'open the scroll or even look inside it' (Rev. 5:3). The seer John reports that he 'wept and wept' until, hearing that the lion of Judah had conquered and is worthy to open the scroll, he turned to see the lamb standing as though slain in the centre of the throne. The praise of the creator with which chapter 4 concluded is now echoed by praise for the redeemer; and the result for those who have been purchased by the blood of the lamb is that they are made 'for our God a kingdom and priests, and they will reign on the earth' (5:10).

Revelation 11:15 describes this redemption in terms of the kingdom of the world becoming the kingdom of God and his Messiah. The continuity between the two ages envisioned here is particularly striking

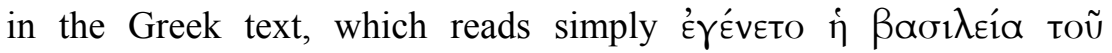

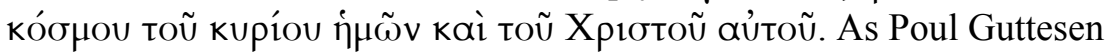
has argued, the compressed syntax suggests that it is the same entity, the same kingdom that finds itself reorientated around a new centre of authority, from that of the world to that of the Lord and of his Messiah. ${ }^{35}$ This new reign is said to extend 'forever and ever'; and it is clearly only in the context of this reign of God and his Messiah that the earthly reign of those purchased by the blood of the lamb described in 5:10 becomes possible; and so their reign too can be said to last 'forever and ever' (22:5). As in chapter 5, the response to all of this can be nothing other than worship, and the prerequisite of this worship is

35 Poul Guttesen, 'Leaning Into the Future: The Kingdom of God in the Theology of Jürgen Moltmann and the Book of Revelation' (Ph.D. dissertation, University of St Andrews, 2005). A revised version of Guttesen's dissertation is now due to be published by Wipf and Stock in 2009. 
the laying down before the throne all other claims to power and authority. In the description of the final judgement within the hymn that follows, then, a striking contrast is drawn between, on the one hand, the rewarding of God's servants, prophets, saints - those who fear his name, both small and great-and, on the other hand, the destruction of those who destroy the earth $(11: 18)$.

According to Revelation, fear, reverence, and the worship of God stand over and against the destruction of his earth. ${ }^{36}$ To honour God as creator and Lord, to heed the call of what John calls elsewhere the 'eternal gospel' (14:7-8), requires in the first instance the acknowledgement that no mere human being can bear the title of lord or god; as mere creatures, awe and worship is what is demanded. It is only in reverencing God the creator and redeemer that human beings join in the worship of all of creation that resounds in the heavenly throne room. In worship, human beings find their appropriate place alongside the rest of creation within the economy of God's kingdom; and it is only in this that they become able to rule in his earth, and to rule in a way that does not lead to the earth's destruction.

The future of earth, however, is finally something given by God. This future is described with vivid imagery in chapters 21-22 of Revelation, and there is a strong emphasis here on all of creation reaching the telos for which it is intended. Thus, to pick one theme among many, there are echoes of the early chapters of Genesis, echoes which call attention not only to creation's restoration but also to its transformation, to its being taken beyond what it was in the beginning to become something genuinely new. If waters and darkness were there from the start of the first creation according to Genesis 1:2, the sea and night have no more place in the new (Rev. 21:1; 22:5); and the results of the tragedy of Genesis 3 - death, sorrow, mourning, pain, and curse (Rev. 21:4; 22:3) — are thus not only absent from the new creation but even the potential for them ever to pose a threat again is permanently

\footnotetext{
36 Most commentators assume without argument that 'earth' in this verse is merely equivalent to people (or God's people) here. See, e.g., David E. Aune, Revelation 6-16 (WBC 52b; Nashville: Thomas Nelson, 1998): 645; G. K. Beale, The Book of Revelation: A Commentary on the Greek Text (NIGTC; Grand Rapids: Eerdmans, 1999): 615-16. But this would be an unusual use of 'earth'. Its plain meaning should be retained, even if for John the destruction of the earth occurs indirectly as a result of the corruption, idolatry, and violence of those who live in it.
} 
removed. ${ }^{37}$ Yet the new creation is not ex nihilo, ${ }^{38}$ for it is a making of 'all things' new, a restoration of life and a healing of the nations, with space even for the glory of the kings of the earth to be brought in through the ever open gates of the New Jerusalem (21:24-25). If John has hesitated earlier in his book to repeat Isaiah's claim that the whole earth is full of God's glory (Rev. 4:8; cf. Isa. 6:3), ${ }^{39}$ the coming of the one 'who is and was and is to come' means that in this new heaven and new earth God is indeed fully present with his people and his glory can truly be said to suffuse all things (21:3, 22-24).

These images of hope and judgement in Revelation, as with those in Romans 8 and 2 Peter 3, may seem like fantasies that have little bearing on life in the here and now; but I suggest that - for those "with eyes to see'- they have the potential to serve as a powerful source of encouragement and motivation for even those today who seek to go about the humble task of living rightly in creation and caring for the earth. In the context of Revelation, the images serve above all to challenge complacency and to encourage perseverance among John's readers, whose putative situations seem, based on the messages to the seven churches, to range from reasonably comfortable accommodation with the surrounding culture to experiences of persecution of one kind or another. For all of those tempted to revere false gods, to give in to the pressure to conform and to compromise their faith, John challenges them to fear and worship only the creator and judge of the world, the one who 'made heaven and earth, the sea and the springs of water' (14:7). For those who are tempted to give up their faithful witness, John encourages them that the victory has already been won and that, no matter how desperate things may appear in the present, God's good purposes for his people and his creation cannot fail.

In our own contemporary context, it can actually seem rather fashionable for a Christian to be concerned about the environment. But it remains worryingly unfashionable and strongly countercultural to actually contemplate doing anything much about it; and I suspect that many of us will become profoundly weary, if we are not already, of

37 For a more fully-developed argument of this point, see Jonathan Moo, 'The Sea That Is No More: Rev 21.1 and the Function of Sea Imagery in the Apocalypse of John', Novum Testamentum 51 (2009): 148-67.

38 Adams, Cosmic Catastrophe, 238, claims that for first-century writer this notion was not even a genuine option in any case.

39 See the brief discussion of Rev. 4:8 and its use of Isa. 6:3 in Bauckham, The Theology of the Book of Revelation (Cambridge: CUP, 1993): 46-47. 
caring about or trying to address a crisis that seems from within our limited perspective to unfold in extreme slow motion, a crisis that has effects usually felt most acutely by communities far away from us, and a crisis that - when fully grasped and understood-easily breeds despair due to its scale, complexity, and apparent intractability. Faithfulness and perseverance are virtues of which we will have great need; and John and other NT writers have much to teach Christians about how they may be cultivated.

\section{Assessment}

The sort of hope we have been tracing fundamentally reorientates the life of the believer, and it does so in ways that are surprisingly crucial for a Christian environmental ethos. In the first instance, it drives out the sort of fear that often lies behind our acquisitiveness and grasping materialism and which prevents us from contemplating radical changes in our individual lives and in our wider societies. In Luke's gospel, it is no coincidence that just before Jesus talks of the Son of Man coming unexpectedly like a thief, he speaks against greed and anxiety, against the sort of greed that causes a rich fool to store up wealth for himself while failing to be rich towards God and against the sort of anxiety that prevents generous, self-sacrificial giving. 'Do not be afraid, little flock,' Jesus says, 'for it is your Father's good pleasure to give you the kingdom. Sell your possessions and give alms' (Luke 12:32-33).

As in 2 Peter's call for pursuing godly acts that hasten in the new creation, biblical hope also encourages an ongoing and persistent commitment to personal virtue through all circumstances, even when things look bleak or when the actions of all of those around us would seem to render the actions of one individual ineffective. In the hope for a future that is at once given by God and yet demands radically new life now, Christians are left without the excuse that unless and until our neighbours change we might as well not change ourselves since it seems to make no difference in the big scale of things. In the context of biblical hope, it is precisely in the big scale of things that individual actions do make a difference; and for Christians to deny the value of the small and apparently insignificant is to deny the possibility of grace, the possibility that God in his faithfulness can honour even our 
feeble efforts; and it is finally to reject our identity as children of God in Christ.

NT hope does not merely encourage personal piety, however. The content of biblical hope reveals the value within God's purposes of the creation itself, a creation that praises the creator simply by being itself and yet whose fate is linked to ours and for whose care in the present age we bear much responsibility. Household stewards, as Jesus' parables remind us, require wisdom to manage well, to discern aright the master's will, and to care and provide for those alongside whom they work; likewise, wisdom of all kinds is necessary for those who seek to care appropriately for the earth, wisdom to perceive the value that it has for its owner, wisdom to discern the master's purposes for it, and wisdom to learn one's own limits in caring for and living within it. And alongside such wisdom must be humility; if God is the owner and master and it is him who is to be revered, it must be only in fear and trembling that the flawed creatures who have been given such responsibility seek to exercise it. For Christians today, this humility must also derive in part from a profound awareness of how we are embedded in and complicit with systems and ways of living that we now recognise as unsustainable and that are contributing to the plight of the poor and of the rest of creation. Christian creation care will not be guilt-driven but nor can it be arrogant, for it proceeds from an awareness of our own limitations and trusts not in ourselves but in the God who by his grace provides the results.

Finally, if NT hope makes strong demands upon those who would seek to live in its light, there is also a promise of joy even in the present for those who await and work for the new creation. If it is in some sense this same creation that is carried over into the new, that finds God's purposes for it realised at the resurrection and restoration of all things, there must be-as Moltmann reminds us - something of the promise of the new creation within the old. ${ }^{40}$ This is consonant with our own experience too; however shot through it is with grief and suffering, human life consists also in profound glimpses of joyperhaps especially in encounters with the world outside ourselves, with creation in all of its otherness, beauty, and awesomeness. If Francis Schaeffer was right when he observed that the death of joy in nature is

40 Moltmann, The Coming of God, 279. 
the beginning of the death of nature itself, ${ }^{41}$ we should be encouraged to reacquaint ourselves with the natural world, to learn more intimately about the creation within which we are embedded, and to honour its creator in our delight in what he has made, in our worship of him, and in our attentiveness to creation's health and well-being. Bonhoeffer went so far as to suggest that we must love this world if we are rightly to anticipate the next. ${ }^{42}$ But the ultimate source of our joy in this ageas in the next-comes from the creator himself. This is the claim of Peter in Acts 3:19-21, who like the other NT writers we have examined, holds together the promise of the present and the future for those who turn to God:

Repent therefore, and turn to God so that your sins may be wiped out, so that times of refreshing may come from the presence of the Lord, and that he may send the Messiah appointed for you, that is, Jesus, who must remain in heaven until the time of universal restoration that God announced long ago through his holy prophets. (NRSV)

Here is motivation for faithful Christian witness and care for the earth; in repenting and in turning to God with all of the ramifications that follow, there is the promise not only of the future restoration of all things but of anticipatory moments of refreshing and relief. As Christians labour to speed on the day of the Lord for which they and all of creation yearn, as they seek to live transformed lives that are in keeping with a world where righteousness is at home, there is hope for glimpses of that glorious future and even instantiations of it in the present as God's will begins to be done on earth, as it is in heaven.

41 Francis Schaeffer, Pollution and the Death of Man (Wheaton, Ill.: Crossway, 1970): 10.

42 See Dietrich Bonhoeffer, Letters and Papers from Prison (ed. E. Bethge; London: SCM, 1953): 157 (letter dated 5 December 1943). It must be admitted that Bonhoeffer's point is slightly different from mine: 'It is only when one loves life and the earth so much that without them everything seems to be over that one may believe in the resurrection and a new world; it is only when one submits to God's law that one may speak of grace; and it is only when God's wrath and vengeance are hanging as grim realities over the heads of one's enemies that something of what it means to love and forgive them can touch our hearts.' 